\title{
Biochemical and physiological aspects of developmental cycle of Colchicum autumnale $\mathrm{L}$.
}

\author{
L. FRANKOVÁ*, H. KOMJÁTHYOVÁ**, K. BÓKA***, O. GAŠPARÍKOVÁ* and M. PŠENÁK**, \\ Institute of Botany, Slovak Academy of Science, Dúbravská cesta 14, SK-84523 Bratislava, Slovak Republic* \\ Faculty of Pharmacy, Comenius University, Kalinčiakova 8, SK-83232 Bratislava, Slovak Republic** \\ Department of Plant Anatomy, Eötvös Loránd University, \\ Pázmany Péter setány 1/C, H-1117 Budapest, Hungary***
}

\begin{abstract}
This study was conducted to examine the individual developmental stages of Colchicum autumnale. We identified the sclerenchymatic tissue in the middle part of the protuberance. This tissue supports the function of protuberance as a kind of hollow diverticulum. On the boundary of the new corm and the shoot a meristematic layer was recognized. We assume that this abscission zone-like structure can initiate dying back of the above-ground part regularly at the end of annual life-cycle. The major part of starch is reutilized in the mother corm during the autumnal stage, supporting sprouting which takes place in the soil. Decline of starch content is paralleled by increasing of total amylolytic activity. From amylolytic enzymes $\alpha$-amylase, $\beta$-amylase and $\alpha$-glucosidase have been identified. The presence of pullulanase and starch phosphorylase was not observed. From free sugars glucose, fructose and sucrose were identified in corms. The level of sucrose increased significantly during winter season.
\end{abstract}

Additional key words: $\alpha$-amylase, $\beta$-amylase, free sugars, geophyte, $\alpha$-glucosidase, protuberance, starch, total amylolytic activity.

\section{Introduction}

The first information of Colchicum autumnale comes from the first century AD. Colchicine is one of the oldest drugs in the Pharmacopea, known mainly as the drug of choice for acute gout. Colchicine was isolated in 1820 and its ability to bind to microtubules was reported in 1960. The biogenesis of the 1-phenethylisoquinoline skeleton of colchicine is well documented (Bilecová and Pšenák 1995), but the enzymes involved have not been studied until now.

The basic morphological feature of geophytes is that the perenniating buds are borne on subterranean storage organ (Raunkiaer 1934). C. autumnale L. is a perennial cormous geophyte with hysteranthous leaves. Dafni $e t$ al. (1981a,b) classified the seasonal patterns of reserve remobilization and allocation in geophytes according to the annual or perennial nature of storage organ and the temporal coincidence (synathy) or separation (hysteranthy) of leaves and flower presence on a plant. The characterization of basal leaves allowed a new interpretation of the shoot structure according to the phyllotaxy. The new corm is mainly formed from the fourth internode, containing two axillary buds ( $3^{\text {rd }}$ and $4^{\text {th }}$ leaf) (Jaehn et al. 1985, Jaehn and Roux 1986). Taxonomical aspects of C. autumnale are covered in detail by Persson (1999). Komjathyová et al. (2000) examined the botanical aspects and certain life-cycle specifities of autumn crocus.

Even the starch biosynthesis and degradation are of central importance for majority of geophytes (Pate and Dixon 1982, Orthen $2001 \mathrm{~b}$ ), the amylolytic process has not been extensively studied in geophytic storage organs until now. The amylolytic process itself and its control mechanism in storage organs of geophytes may provide information essential for understanding the specifities of geophytic life form.

Received 10 January 2003, accepted 25 April 2003.

Abbreviations: BPNFG $_{7}$ - blocked p-nitrophenylmaltoheptaoside; d.m. - dry mass; DW - distilled water; f.m. - fresh mass; $\mathrm{G}_{n}$ - the individual generations; PAGE - polyacrylamide gel electrophoresis; PNPG - $p$-nitrophenyl- $\alpha$-D-glucoside; PNPG $_{5}-p$-nitrophenylmaltopentaoside; $\mathrm{PNPG}_{7}$ - $p$-nitrophenylmaltoheptaoside; TAA - total amylolytic activity.

Acknowledgement: This work was supported by a grant VEGA No. 8241/01.

'Corresponding author; fax: (+421) 254771948, e-mail: psenak@fpharm.uniba.sk 
In this paper first the features of life-cycle and the flexibility of morphological form of corms are described in more detail. Second, the developmental profile of starch, free sugars and that of total amylolytic activity are determined in both mother and daughter corms during the

\section{Materials and methods}

Plant: Colchicum autumnale L. came from a natural population (Malacky, Slovak Republic: $48^{\circ} 26^{\prime} \mathrm{N}, 17^{\circ}$ $02^{\circ}$ E) and was collected in the middle of each month.

Microscopic analyses: Native and fixed (40\% ethanol) plant organs were used for light and stereomicroscopic analyses. For ultrastructural analyses samples were prepared as described by Bóka et al. (2002). Morphometric determination of starch content and ultrastructural analyses were performed by Hitachi 7100 (Tokyo, Japan) transmission electron microscope.

Starch content: For starch extraction and determination perchloric acid and anthrone methods were used (Rose et al. 1991). Absorbance was measured at $625 \mathrm{~nm}$ using Beckman DU-8B (Irvine, USA) spectrophotometer.

Protein content: Extractable proteins from fresh corms were determined according to Bradford (1976) using bovine serum albumin as a standard.

Free sugar content: Fresh corms were homogenized in with $80 \%$ ethanol $\left(3 \times 30 \mathrm{~min}, 50^{\circ} \mathrm{C}\right)$. Extracts were evaporated to dryness and the rest redissolved in $50 \%$ ethanol. Sugars were separated by paper chromatography (Pšenák et al. 1965) (Whatman No. 1, n-butanol:acetic acid:water 4:1:5 - organic phase, three times developed) and standards detected by diphenyl-amine reagent $(0.1 \mathrm{~g}$ of aniline and diphenyl-amine in $16 \mathrm{~cm}^{3}$ of acetone diluted by $1 \mathrm{~cm}^{3}$ of $85 \% \mathrm{H}_{3} \mathrm{PO}_{4}$ ). Visualization of standards was performed at $100^{\circ} \mathrm{C}$. Individual sugars were quantified by anthron method.

Analyses of fructans: Low molecular mass fructans were extracted by $80 \%$ ethanol $\left(60^{\circ} \mathrm{C}, 2 \times 30 \mathrm{~min}\right)$ and high molecular mass fructans with distilled water (DW) $\left(90^{\circ} \mathrm{C}, 2 \times 30 \mathrm{~min}\right.$ ) respectively (Marschall et al 1998 ). Separation and detection of those polysaccharides was assayed as described Savitch et al. (2000).

Enzyme preparation and determination of enzyme activities: Corms were pulverised in presence of liquid nitrogen, washed with excess of cooled acetone $\left(-50^{\circ} \mathrm{C}\right)$ and dried. Acetone-dried material ( $1 \mathrm{~g}$ ) was extracted with $0.1 \mathrm{M}$ Na-phosphate buffer, $\mathrm{pH} 7.0$ in presence of Polyclar $A T$. After extraction $(3 \times 30 \mathrm{~min})$ and centrifugation $(3000 \mathrm{~g}, 20 \mathrm{~min})$ the proteins in supernatants were precipitated by ammonium sulphate (70\% annual life-cycle. Third, the individual enzymes involved in amylolytic process of the first developmental stage were partly characterized. The results obtained are discussed in relation to the strategy of hysteranthous life form of geophytes.

saturation). After centrifugation (7000 $\mathrm{g}, 45 \mathrm{~min})$ the sediment was dissolved in buffer used and dialysed. All operations were carried out at $4{ }^{\circ} \mathrm{C}$.

For determination of total amylolytic activity $1.6 \%$ starch, $1 \%$ amylopectin or $1 \%$ amylose (Sigma, St. Louis, USA) were used. The reaction mixture $\left(0.5 \mathrm{~cm}^{3}\right)$ contained enzyme and substrate solution in $0.1 \mathrm{M} \mathrm{Na}$-phosphate buffer $\mathrm{pH} 7.5$ or $0.1 \mathrm{M} \mathrm{Na}$-acetate buffer $\mathrm{pH}$ 5.2. After incubation $\left(10 \mathrm{~min}, 40{ }^{\circ} \mathrm{C}\right)$ the liberated reduced groups were measured by dinitrosalicylic method (Bernfeld 1955). The reduction power was expressed as amount of units with reducing end released from $\alpha$-glucan substrates by combined action of individual amylolytic enzymes and was named as total amylolytic activity (TAA).

Activities of $\alpha$-amylase, $\beta$-amylase and $\alpha$-glucosidase were assayed by using specific substrates: $\mathrm{BPNPG}_{7}$ (Ceralpha Kit, Megazyme, Bray. Ireland) for $\alpha$-amylase, PNPG $_{5}$ - (Betamyl, Kit, Megazyme, Bray, Ireland) for $\beta$-amylase and PNPG - (Sigma, St. Louis, USA) for $\alpha$-glucosidase. The reaction mixture of final volume $0.25 \mathrm{~cm}^{3}$ contained enzyme solution, $0.1 \mathrm{M} \mathrm{Na}$-acetate buffer $\mathrm{pH} 5.2$ and substrate solution $(545 \mu \mathrm{g} \mathrm{BPNPG}$, $475 \mu \mathrm{g} \mathrm{PNPG}$, or $250 \mu \mathrm{g}$ PNPG). After incubation $\left(10 \mathrm{~min}, 40^{\circ} \mathrm{C}\right)$ the reaction was stopped by $1.5 \mathrm{~cm}^{3}$ of $1 \% \mathrm{Na}_{3} \mathrm{PO}_{4}$ and absorbance was measured at $400 \mathrm{~nm}$. The amount of p-nitrophenol released was calculated according to instruction of manufacturer.

Starch phosphorylase was measured according to Steup (1990).

Pullulanase activity was estimated as described for TAA using $1.25 \%$ pullulan (Sigma, St. Louis, USA) instead of starch as substrate. The reaction was stopped after $6 \mathrm{~h}$ incubation at $40^{\circ} \mathrm{C}$.

Non-denaturating PAGE: Proteins in partially purified enzyme solution were separated by native PAGE on $7 \%$ polyacrylamide gels containing starch as substrate (final concentration $0.25 \%$ ). Electrophoresis was carried out approximately $2 \mathrm{~h}$ at $150 \mathrm{~V}, 500 \mathrm{~mA}, 4{ }^{\circ} \mathrm{C}, \mathrm{pH} 8.5$. (Mini-Protean III slab cell apparatus, Bio-Rad, Richmond, USA). After electrophoresis the gels were incubated in $0.1 \mathrm{M}$ Na-phosphate buffer, $\mathrm{pH} 6.0$ for $6 \mathrm{~h}$ at $40{ }^{\circ} \mathrm{C}$. The gels were stained with iodine solution (2.5 $\mathrm{mM} \mathrm{I}_{2}$ and $0.5 \mathrm{mM} \mathrm{KI}$ ) (Doehlert et al. 1982) for $6 \mathrm{~h}$, than washed with DW and fixed in $30 \%$ methanol in the presence of $5 \%$ acetic acid. The amylase activities appeared as white, pink or bluish bands on dark purple 
background (Kakefuda and Duke 1984). The proteins were stained with the silver method (Heukeshoven and Dernick 1985).

\section{Results}

Morphology and anatomy of $C$. autumnale: At the end of June the upper part of the plant died-back already, the rest of the mother corm and two buds for future generation are located on the ripe corm (Fig. 1A), which as a whole is enclosed by several dry scale-like leaves tunics. One bud $\left(\mathrm{G}_{\mathrm{n}+1}\right.$, Fig. $\left.1 A\right)$ is located on a special organ called protuberance (dropper) (De Hertogh and Le Nard 1993) and the second one - $\mathrm{G}^{*}{ }_{n+1}$ - is positioned on the opposite side, on the upper part of the corm. The first bud so called "regular one" gives rise to a new corm regularly each year at the end of August. The second bud - "irregular one" - gives rise to a new cormlet depending on the size (the amount of reserves) of the mother corm. Each new cormlet has two new buds $-\mathrm{G}_{n+2}, \mathrm{G}^{*}{ }_{n+2}$, so that the regular bud ensures the plant continuity by annual corm replacement. The irregular bud ensures the vegetative reproduction. After differentiation of the new shoot from regular bud the original ripe corm becomes a mother corm (a storage organ).

The life-cycle of the new shoot starts after summer dormancy period, i.e. at the end of August. A new corm and shoot differentiation is accompanied by formation of so called inner furrow on the mother corm. The new shoot is in flower during September. After flowering the development of the future above-ground parts (leaves, stem and fruits) starts in the soil without light. The upper parts of leaves appear near the soil surface at the latest part of autumn. In this form a plant overwinters. All these events represent only the first stage of the life-cycle of $C$. autumnale. The second stage represents photosynthetically active period which lasts only three months (March - June). During this period the individual organs of vegetative part are growing intensively and the storage compounds are formed in the ripening corm. The programmed senescence of above-ground part begins at the end of May. At the same time the mother corm gradually disappears and the fruits are ripening. In addition to seeds a ripe corm without roots equipped with two buds remains after each annual life-cycle. A corm in this form enters into summer dormancy and the life-cycle of the plant starts over again.

Generally the storage organs are of primary importance in the life-cycle of geophytes and those with hysteranthous leaves particularly. The storage organs are usually positioned in appropriate depth in soil. The corm of $C$. autumnale contains an unusual organ - protuberance serving for its positioning. The size of protuberance depends on how deep is the corm positioned in the soil. When a ripe mother corm is shallowly planted into the soil, protuberance of its daughter corm is well developed
Statistics: The data reported are means of the values obtained from three experiments with two replication each.

(Fig. 1A). The same is true for irregular cormlet. The irregular bud is positioned on the upper part of the mother corm (about $2 / 3$ higher than position of regular bud) so the protuberance of irregular cormlet (Fig. $1 B$ ) must help the new plantlet to get deeper into the soil, where the new lineage of irregular bud can be initiated. The cormlets of C. autumnale seedlings have special morphological characteristics (Fig. 1C). Their structure enables probably together with contractile roots the gradual penetration of corms into a suitable depth of ground. In addition the appearance of thick roots was observed (Fig. 1C). This type of roots was first described by Rimbach (1897). There is no information about the role of thick roots. As for the corms that are localized deep enough in the soil, the protuberance of a corm is rather short ( $3-5 \mathrm{~mm}$ ).

The tissue composition of protuberance indicated the presence of a sclerenchymatic tissue inside this specialized organ (Fig. 1D). Because of mechanical and elastic properties of sclerenchymatic cells the protuberance can gradually descend into the ground.

On the boundary of the new cormlet and the corresponding shoot a meristematic cell layer was identified (Fig. $1 E, F$ ). According to the structure in this zone, it reminds the abscission zone of the leaves.

Light microscopic analyses showed also that the cells of ripe corm - $\mathrm{G}_{\mathrm{n}}$ are full of starch (Fig. $1 G$ ) at the end of photosynthetically active period (June). After ten months the major part of cells of this mother corm had already remobilized starch by the end of April (Fig. $1 H$ ). At this stage the rest of starch is localized mainly in cells around the vascular bundles of the mother corm. To the end of May the cells of mother corm become free of starch (Fig. $I I$ ) and the rest of corm succumbs to decomposition.

Biochemical analyses: Starch represented almost $50 \%$ of corm dry mass. The presence of fructans as another storage material has not been observed. The developmental profiles of starch content in old and new corms (Fig. $2 A$ ) indicate that an active starch reutilization in mother corm parallels the differentiation and growth of the new shoot, flowers and later on of the whole future aerial part of autumn crocus. The main part of the starch content of mother corm is used-up to the beginning of the winter season. The rest of the starch content in old corm is completely reutilized to the second developmental stage (March-May). During the first half of this phase the photoassimilates are still not accumulated in the form of starch in the new corm. They are consumed mainly for growth of photosynthetically active parts (stem and leaves) and the reproductive structures (capsules with 

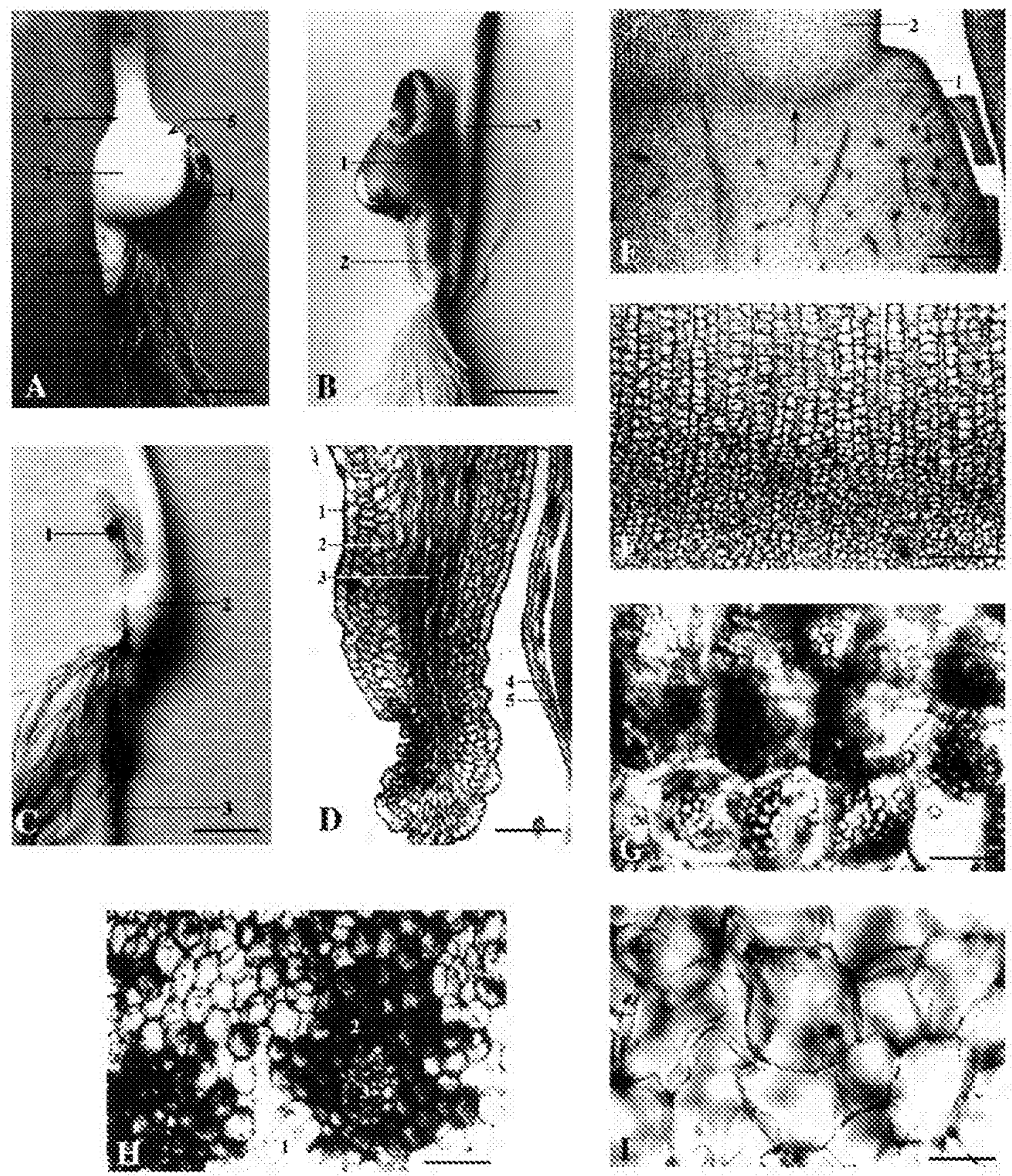

Fig. 1. Structural characteristics of corms of Colchicum autumnale L.: $A$ - ripe corm at the end of June, 1 - the rest of the old corm $\left(G_{n-1}\right), 2$ - the new corm $\left(G_{n}\right), 3$ - the well developed protuberance, 4 - position of the renewal (regular) bud for corm $\left(G_{n+1}\right.$ ). 5 - position of the irregular, vegetative bud for corm $\left(\mathrm{G}^{*}{ }_{\mathrm{n}+1}\right), 6$ - position of the meristematic zone $($ bar $=2 \mathrm{~cm}) ; B$ - a new lineage initiated by irregular bud (vegetative reproduction), 1 - an independent corm arisen from the vegetative bud $\left(\mathrm{G}^{*}{ }_{\mathrm{n}+1}\right), 2$ - the well developed protuberance, 3 - the new shoot with the new corm $\left(\mathrm{G}_{\mathrm{n}+2}\right)($ bar $=1 \mathrm{~cm}) ; C$ - a young plant (three-year-old) developed from seed (generative reproduction), 1 - position of the roots in previous year, 2 - the new cormlet with roots one year later, 3 - thick root $(b a r=1 \mathrm{~cm}) ; D$ - a longitudinal section of the protuberance, 1 - epidermal cell layer. 2 - parenchymatic tissue, 3 - sclerenchymatic tissue inside the protuberance, 4 - coleorhize-like remnants, 5 - root $($ bar $=220 \mu \mathrm{m}): E$. the meristematic zone between the new cormlet (1) and the rest of new shoot (2) $($ bar $=500 \mu \mathrm{m}) ; F$ - a segment of the meristematic layer $($ bar $=200 \mu \mathrm{m}) ; G$. H,I - starch distribution within the life cycle of a ripe corm (from June to May) $G$ - a ripe corm $\left(\mathrm{G}_{\mathrm{n}}\right)$ at the end of June $($ bar $=30 \mu \mathrm{m}) ; \mathrm{H}-\mathrm{a}$ mother corm in April, next year $($ bar $=80 \mu \mathrm{m}), 1$ - depleted storage cells, 2 - parenchymatic cells around the vascular bundles are full of starch, 3 - vascular bundle ; $I$ - the cells of a mother corm are completely free of starch at the end of May, next year $(b a r=30 \mu \mathrm{m})$. 
seeds). The reserve formation began in the middle of April and lasted two months, when the daughter corm became ripe.

The profile of specific amylolytic activity (TAA expressed per mg proteins) (Fig. $2 B$ ) within the life-cycle corresponds with the complete starch remobilization in a mother corm (Fig. $2 A$ ). The specific amylolytic activities were significantly increased in both mother and daughter corms, especially during March and April.

TAA of the mother corm was measured with different

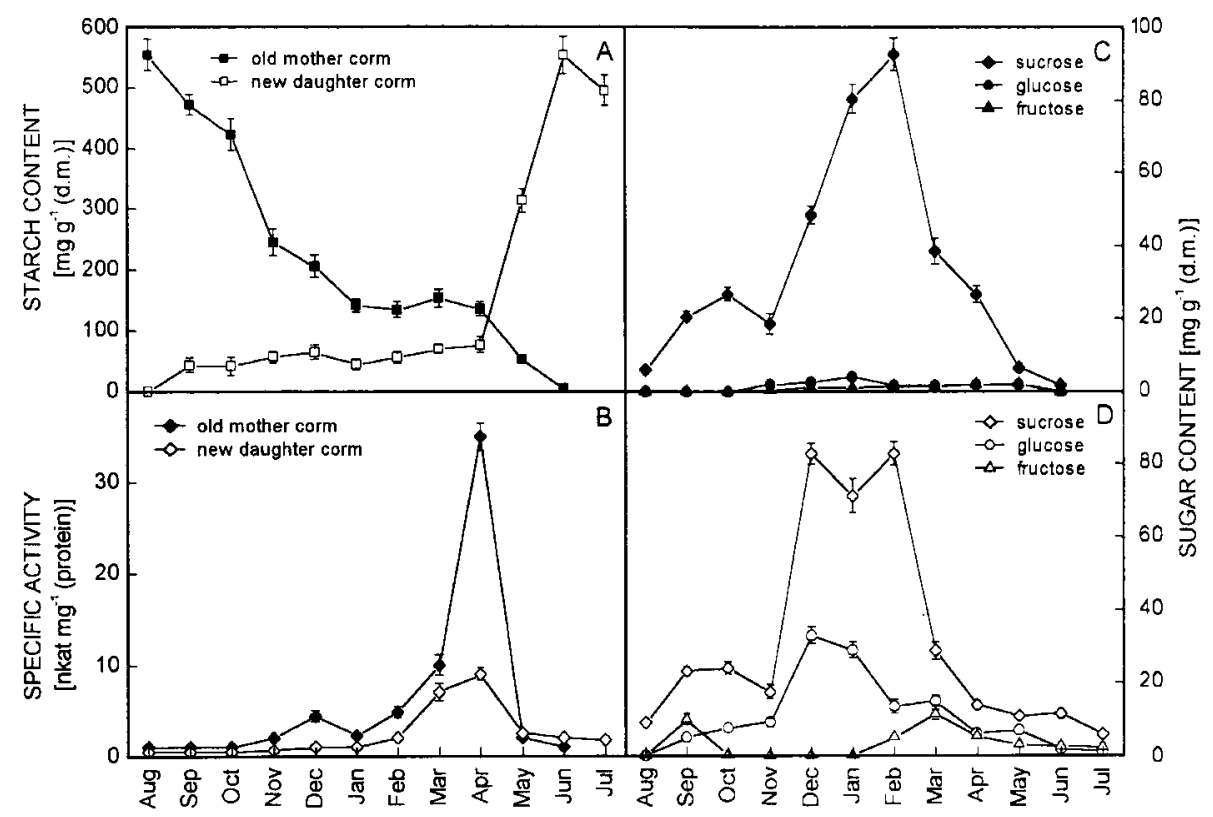

Fig. 2. Developmental changes in starch content $(A)$, specific amylolytic activity at pH $7.5(B)$ and free sugars in mother $(C)$ and daughter corm $(D)$ during the whole life-cycle of $C$. autumnale. Means $\pm \mathrm{SE} . n=6$.
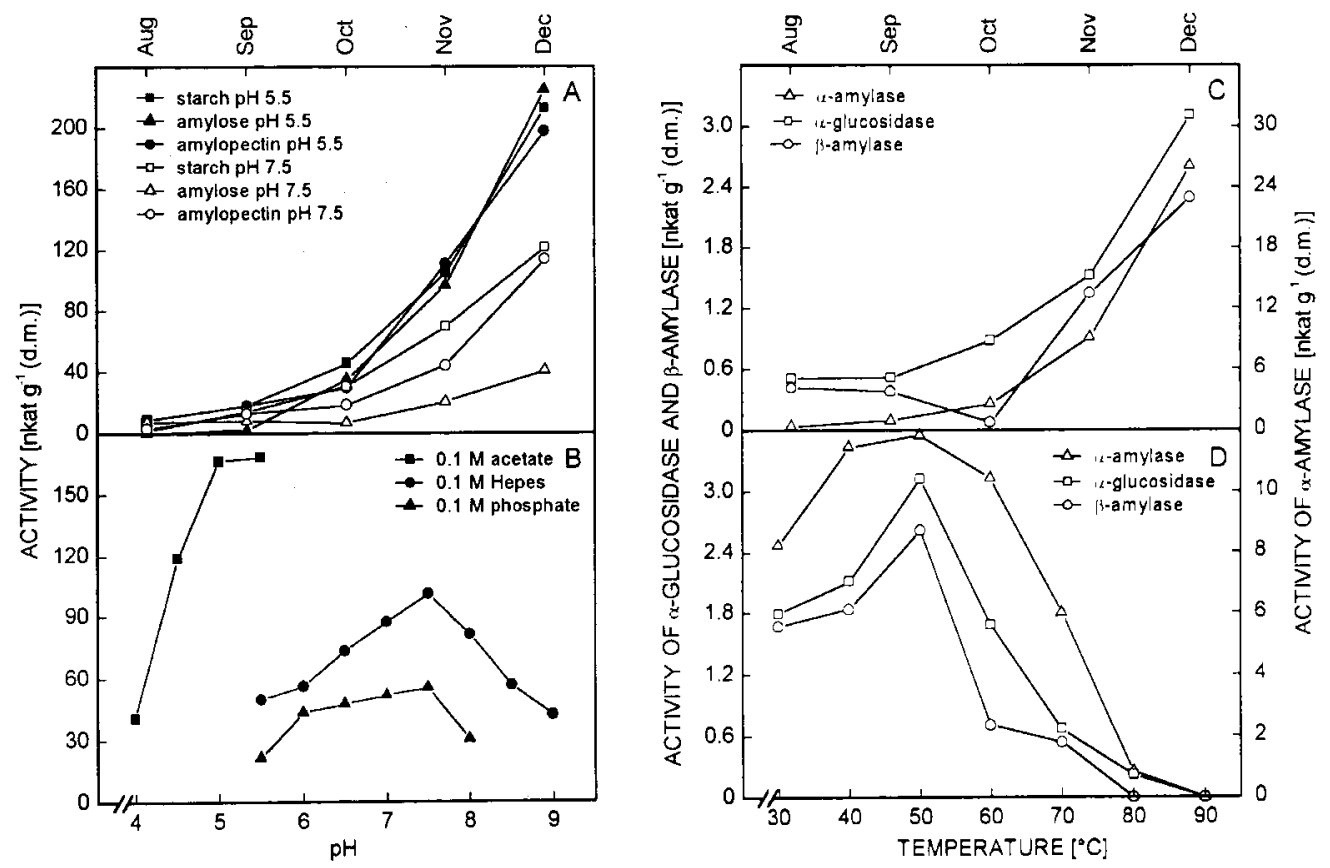

Fig. 3. Amylolytic process of mother corm during the first (autumnal) stage of the life-cycle of $C$. autumnale: $A$ - total amylolytic activity (TAA) assayed with different non-specific substrates at $\mathrm{pH} 5.5$ and $7.5 ; B-\mathrm{pH}$ optimum of TAA using starch as substrate; $C$ - activities of amylolytic enzymes using the specific substrates: blocked $p$-nitrophenylmaltoheptaoside $\left(\mathrm{BPNFG}_{7}\right)$ for $\alpha$-amylase, $p$-nitrophenylmaltopentaoside $\left(\mathrm{PNPG}_{5}\right.$ ) for $\beta$-amylase and $p$-nitrophenyl- $\alpha$-D-glucopyranoside (PNPG) for $\alpha$-glucosidase; $D$ - temperature optimum of identified amylolytic enzymes. 
substrates at two pH values (Fig. $3 A$ ). Using starch as substrate, two pH optima (pH 5.5 and 7.5) were identified (Fig. $3 B$ ). Starch was found as the best substrate at $\mathrm{pH} 7.5$ whereas at $\mathrm{pH} 5.5$ TAA measured with all non-specific substrates used was almost identical (Fig. 3A). To find out which enzymes are taking part in the amylolytic process, three specific substrates were used: $\mathrm{BPNFG}_{7}$ for $\alpha$-amylase, $\mathrm{PNPG}_{5}$ for $\beta$-amylase and PNPG for $\alpha$-glucosidase. The relation proportion of these enzymes (Fig. $3 C$ ) is: $\alpha$-amylase $>\alpha$-glucosidase $>\beta$-amylase. Very low pullulanase and no starch phosphorylase activities were detected. The $\alpha$-1,4-glucanhydrolases present in a mother corm have $\mathrm{pH}$ optimum in acidic region and are most active around $50^{\circ} \mathrm{C}$ (Fig. $3 D$ ). Both TAA (Fig. $3 A$ ) and the activities of individual amylolytic enzymes (Fig. 3C) gradually increase from August to December.

By using of native PAGE eight bands of starchdegrading enzymes were observed (Fig. $4 A$ ). In mother corm the level and spectrum of soluble proteins did not change significantly during autumnal developmental stage (Fig. 4B). The number and intensity of the bands corresponding to $\alpha$-glucanhydrolase activity increased what was in accord with developmental profile of TAA and individual amylolytic enzymes.

Both mother and daughter corms contain glucose, fructose and sucrose as free sugars (Fig, 2C,D). The content of sucrose has a maximum during winter season. Except of sucrose the amount of hexoses in the daughter corm (Fig. 2D) is higher, than that is in the mother corm.
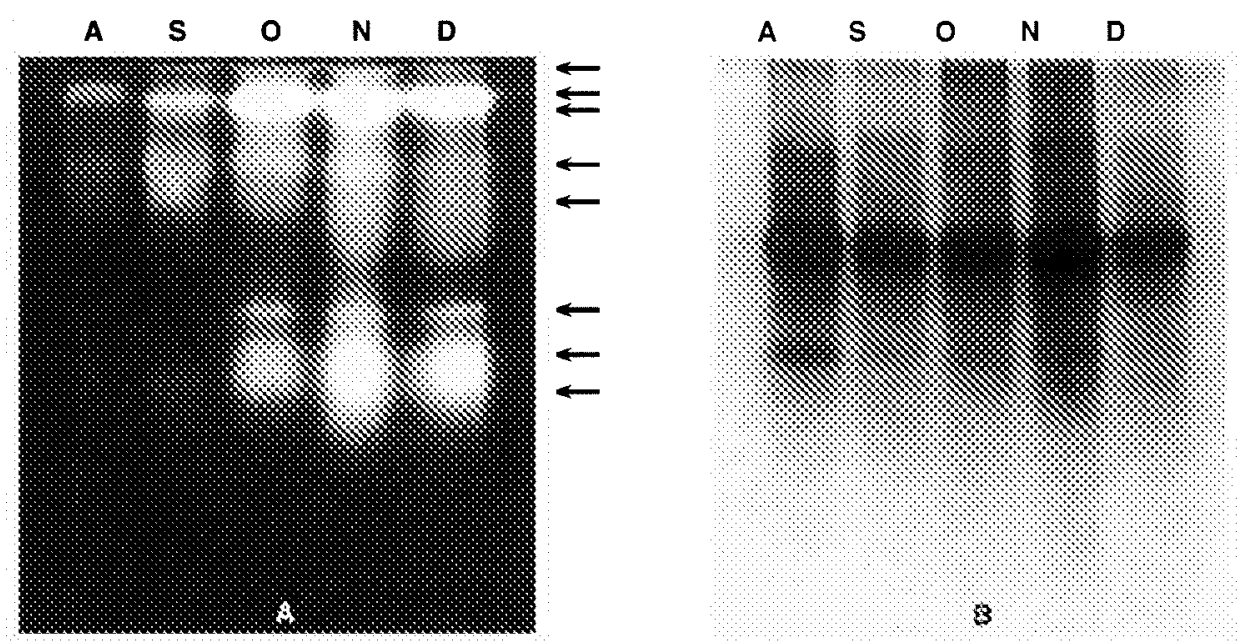

Fig. 4. A - Zymogram of starch-degrading enzymes of mother corm during the the first (autumnal) stage of the life-cycle of $C$ autumnale. The proteins were separated by non-denaturating PAGE in gels containing $0.25 \%$ starch. The gels were incubated in $0.1 \mathrm{M} \mathrm{Na}$-phosphate buffer $\mathrm{pH} 6.0$ and stained with an iodine solution. Except of line $D(40 \mu \mathrm{g}$ proteins), $80 \mu \mathrm{g}$ proteins have been loaded on each line. For preparation of individual enzyme solution $1 \mathrm{~g}$ of acetone dried powder was used. Arrows indicate the position of isoforms of $\alpha-1,4-$ and $\alpha-1,6$-glucan hydrolases. $B$ - Spectrum of soluble proteins of mother corm during the first (autumnal) stage. The proteins were separated by non-denaturating PAGE and stained by silver method. Each line contained $0.5 \mu \mathrm{g}$ proteins; A - August; S - September; O - October; N - November; D - December.

\section{Discussion}

In a young plant (October-November) a special cell-layer was observed between the new cormlet and rest of the shoot (Fig. $1 E, F$ ). It is assumed that this abscission zonelike structure could be involved in the initiation of the dying back of the above-ground part of autumn crocus regularly at the end of annual life-cycle. To shed the above-ground plant part at the end of annual life-cycle is a special feature of geophytes. For $C$. autumnale the vegetative part dies back at the late spring (in June) and undergoes physical destruction. That part of the stem connecting the apex of a ripe corm with vegetative part of the plant dies back too, but is not immediately physically destroyed. This part together with many-layered tunica connects the apex of corm with the soil surface. Such system guides the penetration of the flower stems first and later on the whole new shoot up to the ground surface. In addition to this function the tunics and cataphyll tubes are assumed to reduce the water loss and to protect the corms as storage organs from frost (Rees 1989). The role of the dry remnants in photoperiod affected flowering was described first by Gutterman and Boeken (1988), and Gutterman (1989) for C. tunicatum.

Futher protection of plant organs from frost is the conversion of high molecular mass storage saccharides to 
those of low molecular mass in response to cold (cryoprotection) (Hobson and Davies 1977, Guy et al. 1992). The presence of high content of sucrose in both corms during the winter season (Fig. 2C,D) is in accordance with these assumptions. On the other hand, the amount of hexoses is much higher in daughter corm what probably indicates the presence of hypometabolism and respiration in this corm, whereas the mother corm is a storage organ with a minimum of metabolic activity.

The polysaccharides are the most common storage materials of perennial plants (Buckeridge et al. 2000, Pate and Dixon 1982). They are represented first of all by storage starch, following by fructans and storage cell wall polysaccharides (mannans, glucomannans, galactomannans, xyloglucans and galactans). Thanks to good solubility in water only fructans can interfere with osmotic relationships of the plants. Both starch and storage cell wall polysaccharides are osmotically inert. Starch degradation products are used mainly as carbon and energy sources (Orthen 2001a).

Starch degradation is the central process during the first developmental stage of $C$. autumnale. Because of the facts that from the half of August till September there are no roots and photosynthetically active leaves, the mother corm supplies all the building blocks (reduced $\mathrm{C}, \mathrm{N}$ and minerals) and water for development of the new shoot in the soil. Both the rapid growth and development of young leaves and capsules are supported mainly by reduced carbon from the mother corm (October - December). These processes are accompanied by a rapid decline of the starch content and by increase of TAA in the mother

\section{References}

Bernfeld, P.: Amylases, $\alpha$ and $\beta$. - Methods Enzymol. 1: 149$158,1955$.

Bilecová, A., Pšenák, M.: [Biochemical aspects of colchicinoids in Colchicum autumnale L.] - Chem. Listy 89: 100-110, 1995. [In Slovak.]

Bóka, K., Jakab, J., Király, I.: Comparison of the effect of differential fungal elicitors on Rubia tinctorum $\mathrm{I}$. suspension culture. - Biol. Plant. 45: 281-290, 2002.

Bradford, M.: A rapid and sensitive method for the quantitation of microgram quantities of protein utilizing the principle of protein dye binding. - Anal. Biochem. 72: 248-256, 1976

Buckeridge, M.S., Pessoa dos Santos, H., Tiné, M.A.S.: Mobilisation of storage cell wall polysaccharides in seeds. Plant Physiol. Biochem. 38: 141-156, 2000.

Chapin III., F.S., Schulze, E.-D., Money, H.A.: The ecology and economics of storage in plants. - Annu. Rev. Ecol. Syst. 21: 423-442, 1990.

Dafni, A., Cohen, D., Noy-Meir, I.: Life-cycle variation in geophytes. - Ann. Missouri bot. Garden 68: 652-660, 1981a.

Dafni, A., Shmida, A., Avishai, M.: Leafless autumnalflowering heophytes in the Mediterranean region phytogeographical, ecological and evolutionary aspects. Plant Syst. Evol. 137: 181-193, $1981 \mathrm{~b}$.

De Hertogh, A.A., Le Nard, M.: The Physiology of Flower corm.

The profile of specific amylolytic activity during the second developmental stage corresponds with the complete starch remobilization in mother corm (Fig. $2 A, B$ ). The highest specific amylolytic activity is a result of a rapid decrease of proteins in mother corm (data not shown). The growth and development of aboveground part is very intensive at this stage, so the photoassimilates and starch degradation products from old corm can not saturate the carbon demands of the vegetative part. Therefore the plant has to reutilize a certain amount of already stored starch from daughter corm. This process is represented by high specific amylolytic activity in the new corm (Fig. 2B). The starch degraded by this amylolytic activity may reflect the somatic costs of reproduction (Méndez 1999, Chapin et al. 1990). In spite of the starch degradation in the new corm, its final level reached that of starch in mother corm the year before (Fig. $2 A$ ).

The storage starch formation is restricted to a relatively short period (May - June) of a ripening new corm (Fig. 1 $G, 2 A$ ). There is no information about starch biosynthesis in corms of $C$. autumnale at the subcellular and enzymological level. On the other hand, starch formed is realocated from the mother corm in the course of ten months (August - May) (Fig. 1H,I). The results obtained by morphological, microscopical and biochemical approaches indicate that starch allocation and reallocation are key processes in the life strategy of Colchicum autumnale $\mathrm{L}$.

Bulbs. - Elsevier Science Publishers, Amsterdam 1993.

Doehlert, D.C., Duke, S.H., Anderson, L.: $\beta$-Amylases from alfalfa (Medicago sativa) roots. - Plant Physiol. 69: 1096$1102,1982$.

Gutterman, Y.: Colchicum tunicatum. - In: Halevy. A.H. (ed.): Handbook of Flowering. Vol. VI. Pp. 234-242, CRC Press, Boca Raton 1989.

Gutterman. Y., Boeken, B.: Flowering affected by daylength and temperature in the leafless flowering desert geophyte Colchicum tunicatum, its annual life cycle and vegetative propagation. - Bot. Gaz. 149: 382-390, 1988.

Guy, C.L., Huber, J.L.A., Huber, S.C.: Sucrose phosphate synthase and sucrose accumulation at low temperature. Plant Physiol. 100: 502-508, 1992.

Heukeshoven, J., Dernick, R: Simplified method for silver staining of proteins in polyacrylamide gels and the mechanism of silver staining. - Electrophoresis 6: 103-112, 1985.

Hobson, G.E., Davies, J.N.: Mitochondrial activity and carbohydrate levels in tuplip bulbs in relation to cold treatment. - J. exp. Bot. 28: 559-568, 1977.

Jaehn, F., Pfirsch, E, Roux, J.: Zur Architektur des Jahressprosses der Herbstzeitlose (Colchicum autumnale L.). - Beitr. Biol. Pflanz. 60: 303-311, 1985. 
Jaehn, F., Roux, J.: Architecture et cycle annuel du colchique adulte (Colchicum autumnale L.). - Bull. Soc. bot. France 133: $225-233,1986$

Kakefuda, G., Duke, S.H.: Electrophoretic transfer as a technique for detection and identification of plant amylolytic enzymes in polyacrylamide gels. - Plant Physiol. 75: 278-280, 1984.

Komjathyová, H., Franková, L., Bóka, K., Pšenák, M.: [Botanical and developmental aspects of Colchicum autumnale L (autumn crocus)]. - Acta Fac. Rerum nat. Univ. comenianae Bot. 40: 67-80, 2000. [In Slovak.]

Marschall, M., Proctor, M.C.F., Smirnoff, N.: Carbohydrate composition and invertase activity of the leafy liverwort Porella platyphylla. - New Phytol. 138: 343-353, 1998.

Méndez, M.: Effects of sexual reproduction on growth and vegetative propagation in the perennial geophyte Arum italicum (Araceae). - Plant Biol. 1: 115-120, 1999.

Orthen. B.: Sprouting of the fructan- and starch-storing geophyte Lachenalia minima: Effects on carbohydrate and water content within the bulbs. - Physiol. Plant. 113: 308 $314,2001 \mathrm{a}$.

Orthen. B.: A survey of the polysaccharide reserves in geophytes native to the winter-rainfall region of South Africa. - South Afr. J. Bot. 67: 371-375, $2001 \mathrm{~b}$.
Pate, J.S., Dixon, K.W.: Tuberous, Cormous and Bulbous Plants. - University of Western Australia Press, Nedlands 1982.

Persson, K.: New and revised species of Colchicum (Colchicaceae) from the Balkan Penninsula. - Plant Syst. Evol. 217: 55-80, 1999.

P̌̌enák, M., Woitowitz, D., Kovács, P., Jindra, A.: [Sugars in Geum urbarum.] - Ćeskoslov. Farm. 14: 397-401, 1965. [In Slovak.]

Raunkiaer, C.: The Life Forms of Plants and Statistical Geography. - Oxford University Press, Oxford 1934.

Rees, A.R.: Evolution of the geophytic habit and its physiological advantages. - Herbetia 45: 105-110, 1989.

Rimbach, A.: Biologische Beobachtungen an Colchicum autumnale. - Ber. deut. bot. Ges. 15: 298-303, 1897.

Rose, R., Rose, C.L., Onii, S.K., Forry, K.R., Durall, D.M., Bigg, W.L.: Starch determination by perchloric acid. - J. agr. Food Chem. 39: 2-11, 1991.

Savitch, E. V., Harney, T., Huner, N. P. A.: Sucrose metabolism in spring and winter wheat in response to hight irradiance, cold stress and cold acclimatisation. - Physiol. Plant. 108, 270-278, 2000.

Steup, M.: Starch degrading enzymes. - Methods Plant Biochem. 3: 103-128, 1990. 